\title{
Seismotectonic implications of the Kyushu-Palau ridge subducting beneath the westernmost Nankai forearc
}

\author{
Jin-Oh Park ${ }^{1,2}$, Takane Hori ${ }^{2}$, and Yoshiyuki Kaneda ${ }^{2}$ \\ ${ }^{1}$ Ocean Research Institute, University of Tokyo, 1-15-1 Minamidai, Nakano-ku, Tokyo 164-8639, Japan \\ ${ }^{2}$ Institute for Research on Earth Evolution, Japan Agency for Marine-Earth Science and Technology, \\ 3175-25 Showa-machi, Kanazawa-ku, Yokohama 236-0001, Japan
}

(Received December 9, 2008; Revised March 30, 2009; Accepted May 11, 2009; Online published October 19, 2009)

\begin{abstract}
The Kyushu-Palau ridge, a remnant arc on the Philippine Sea Plate, subducts beneath the Eurasian Plate along the westernmost part of the Nankai Trough. A seismic reflection profile on strike line images the $\sim 70-\mathrm{km}$ wide Kyushu-Palau ridge where it subducts beneath the toe of the forearc accretionary wedge. The geomagnetic anomaly signature, seafloor topographic features, wide-angle refraction data, and on-land geomorphologic evidence enable us to trace the forearc extension of the subducted ridge up to the east Kyushu. The subducted Kyushu-Palau ridge with excess mass may be relatively buoyant, and thus is more likely to resist subduction upon collision with the overriding plate at depth, leading us to speculate that there is locally large tectonic stress at the contact zone between the subducted ridge and base of the overriding plate. The large stress zone is marked by historic thrust-type intermediate-class (magnitude 6 or 7 ) earthquakes. The flank regions of the subducted buoyant Kyushu-Palau ridge are more likely to tear and result in slab fracturing when the ridge subducts deeper. We propose that the subducted Kyushu-Palau ridge may serve not only as a seismic asperity at depth but also produce the slab fracture as a seismic barrier inhibiting the rupture propagation of the adjacent megathrust earthquakes in the Hyuga segment.
\end{abstract}

Key words: Kyushu-Palau ridge, Nankai Trough, reflection profile, asperity, barrier.

\section{Introduction}

The Nankai Trough subduction zone (Fig. 1), where the Philippine Sea Plate (PSP) subducts beneath the Eurasian Plate to the NNW, is known as one of the convergent plate margins best-suited for studying subduction zone earthquakes. The Nankai subduction zone may be divided into several discrete domains (A through $\mathrm{D}$, and $\mathrm{Z}$, Fig. 1) marked by the historic megathrust earthquake rupture, each of which roughly corresponds to a geologically well-defined forearc basin (Sugiyama, 1994). The westernmost domain $\mathrm{Z}$ (referred to as Hyuga segment) is distinguished from the other four domains (A through D) from a viewpoint of megathrust earthquake rupture behavior. For instance, while the other four domains have magnitude 8 earthquakes with a recurrence interval of 100-200 years (Ando, 1975), the domain $\mathrm{Z}$ is marked by just magnitude 6 or 7 earthquakes with a recurrence interval of 10-20 years (Shiono et al., 1980). Such a contrast can result from relatively weak interplate coupling associated with the steeper slope angle of the subducting PSP at domain Z than at the other four domains (e.g., Nishimura et al., 1999).

In the Hyuga segment (domain $\mathrm{Z}$ ), the Kyushu-Palau ridge, which is a remnant arc associated with backarc spreading of the Shikoku Basin of about 30-15 Ma (Kobayashi and Nakada, 1978; Okino et al., 1994), appears

Copyright (c) The Society of Geomagnetism and Earth, Planetary and Space Sciences (SGEPSS); The Seismological Society of Japan; The Volcanological Society of Japan; The Geodetic Society of Japan; The Japanese Society for Planetary Sciences; TERRAPUB. to be one of the major structural features. A bathymetric survey result of project Kaiko (Le Pichon et al., 1987) suggested that the Kyushu-Palau ridge might act as an indenter for the westernmost Nankai Trough margin, and the front of the indenter was situated under the accretionary prism. Yamazaki and Okamura (1989) inferred from bathymetric and magnetic anomaly data that the Kyushu-Palau ridge subducted beneath the forearc wedge of this segment. An Ocean Bottom Seismograph (OBS) wide-angle seismic study (Ichikawa, 1997), whose survey lines are shown in Fig. 1, presented crustal velocity structure models of the forearc sedimentary layers showing strong deformation, which may be attributed to the Kyushu-Palau ridge subduction. Geomorphologic observations (Nakada et al., 2002) at the eastern part of Kyushu reported that the Miyazaki Plain (Fig. 1) has been significantly uplifting since the Late Pleistocene, probably due to the Kyushu-Palau ridge subduction. A recent seismic tomography study (Tahara et al., 2008) suggested the subduction of the Kyushu-Palau ridge at $\sim 30 \mathrm{~km}$ depth below the Miyazaki Plain. Despite those several geologic and geophysical inferences, there is little direct evidence such as seismic reflection images, to confirm the Kyushu-Palau ridge subduction. Moreover, the role of the subducting Kyushu-Palau ridge in affecting the Hyuga megathrust earthquakes is poorly understood.

In this paper, we present multichannel seismic (MCS) reflection and geomagnetic data, which reveal the KyushuPalau ridge subducting beneath the Hyuga forearc accretionary wedge. We describe the structural features related to 


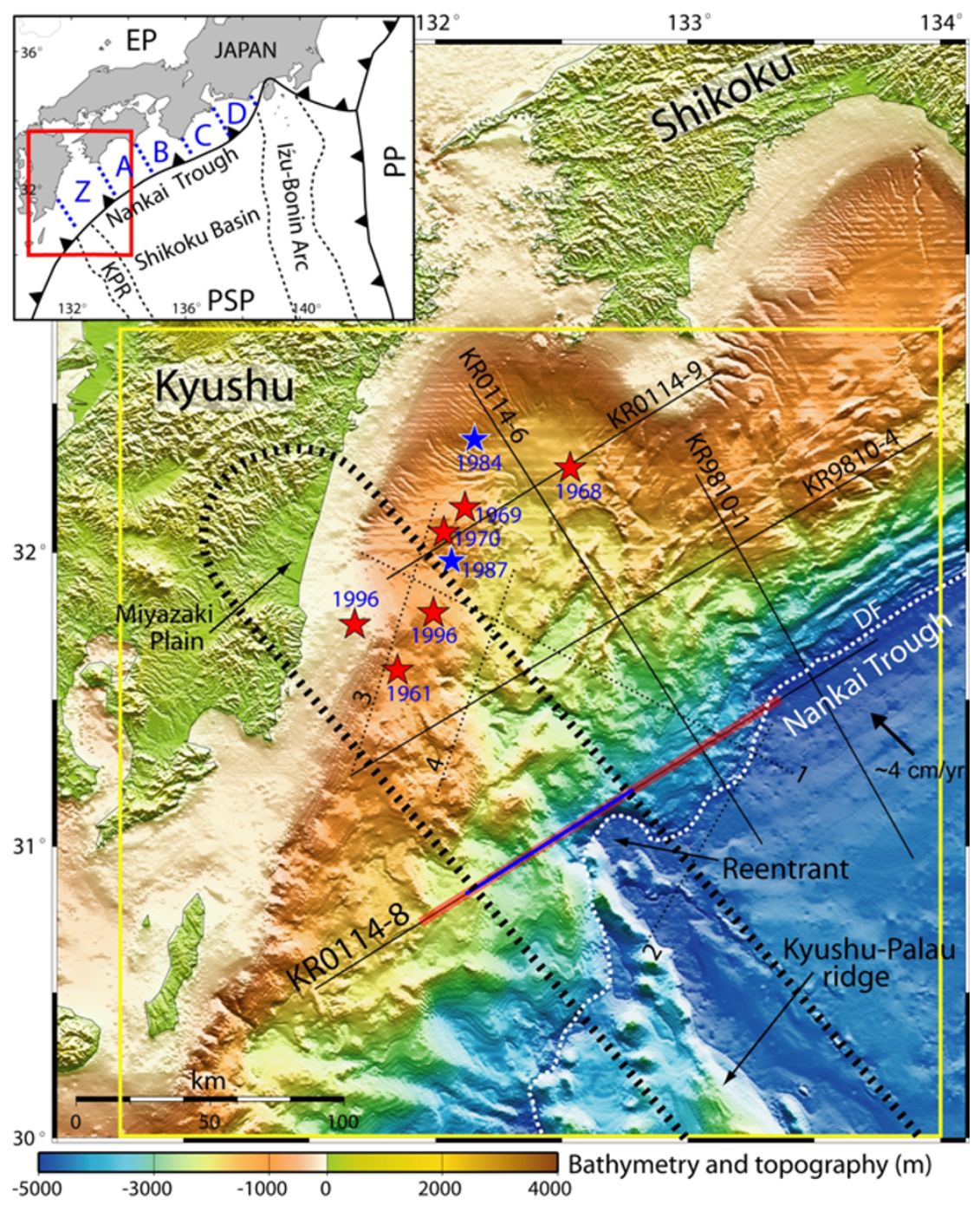

Fig. 1. Bathymetry map and locations of MCS (black thin; this study) and OBS (black dotted; Ichikawa, 1997) lines in the westernmost Nankai Trough margin off southwest Japan. Inset is a regional tectonic map showing the location of the study area (red box). The Philippine Sea Plate subducts beneath the Eurasian Plate to the northwest with convergence rate $\sim 4 \mathrm{~cm} / \mathrm{yr}$ (Seno et al., 1993). The Nankai subduction zone may be divided into five discrete domains (A through D, and Z) marked by distinct megathrust earthquake ruptures (Ando, 1975; Sugiyama, 1994). Heavy black dotted line marks the inferred Kyushu-Palau ridge in the Hyuga segment (domain Z). The forearc region within the heavy black dotted line shows disturbed seafloor topography compared with the forearc wedge off Shikoku Island, probably due to the ridge subduction. Intermediate-class $(6.5 \leq M \leq 7.5)$ earthquakes (Japan Meteorological Agency Catalog) occurred in the Hyuga segment since 1960's are marked in star. Their focal mechanism solutions include reverse (red) and normal (blue) faultings. White dotted line marks deformation front (DF). Heavy red and blue parts on MCS line KR0114-8 are shown in Fig. 2. Geomagnetic and microseismicity data within a large rectangle with yellow thin line are shown in Figs. 3 and 4 . EP, Eurasian Plate; PSP, Philippine Sea Plate; PP, Pacific Plate; KPR, Kyushu-Palau ridge.

the ridge subduction and demonstrate its seismotectonic implications, based on the prestack depth migrated MCS profile, geomagnetic anomaly signature, seafloor bathymetry, and seismicity.

\section{Geophysical and Geologic Constraints on the Kyushu-Palau Ridge Subduction: Data and In- terpretation}

We have conducted many MCS surveys in the western Nankai Trough subduction zone, using R/V Kairei of the Japan Agency for Marine-Earth Science and Technology (JAMSTEC) since 1998. For deep-penetration seismic imaging, a large volume ( 200 liters) air gun array was used as the controlled sound source. The MCS data recording was done with a 120-channel streamer $(3 \mathrm{~km}$ long) or 160-channel streamer (4 km long) with $25 \mathrm{~m}$ group spacing. Figure 1 shows the positions of the MCS lines in the westernmost Nankai margin. Data processing included trace editing, pre-filtering, spherical divergence correction, signature deconvolution, CMP (Common Mid Point) sort, multiple suppression by parabolic radon transform, and prestack depth migration (PSDM). The velocitydepth model for the PSDM was iteratively constructed by migration velocity analysis (e.g., Liu and Bleistein, 1995). Wide-angle OBS data (Ichikawa, 1997) guided the velocity analysis.

On PSDM profile KR0114-8 (Fig. 2), parallel to the Nankai Trough, a strong reflection from the oceanic crust of the PSP is almost continuously traceable between shot point (SP) 2000 and 5200, as the PSP subducts beneath the forearc accretionary wedge. The subducting oceanic crust shows southwestward deepening down to $10 \mathrm{~km}$ 
Line KR0114-8

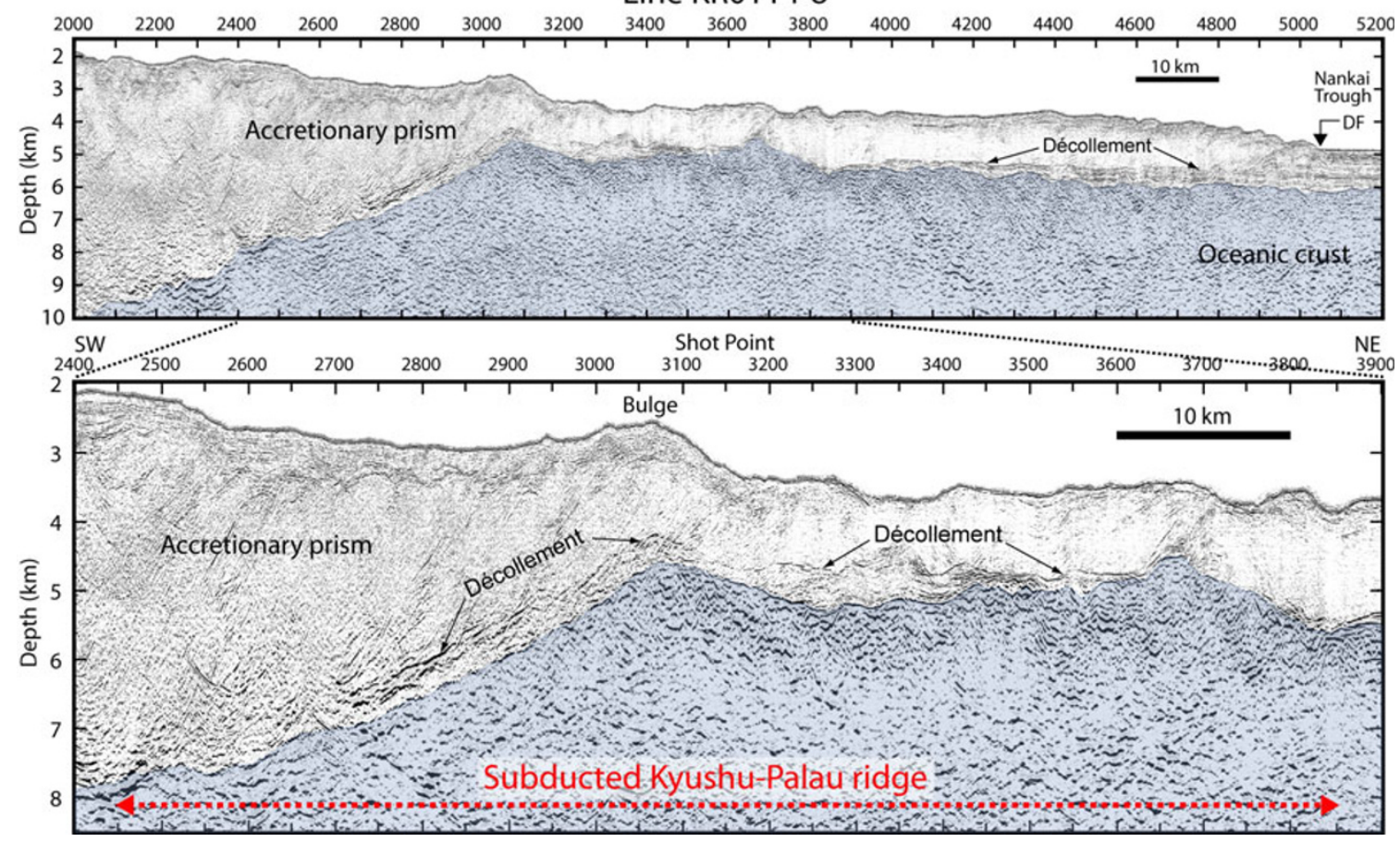

Fig. 2. Prestack depth migrated MCS profile on line KR0114-8 showing the subducted Kyushu-Palau ridge. An area between SP 2400 and 3900 of upper profile is enlarged into lower profile, whose locations are shown by heavy red and blue parts, respectively, on the MCS line in Fig. 1. Subducting oceanic crust is shaded in light blue. Vertical exaggeration is $4 \times$.

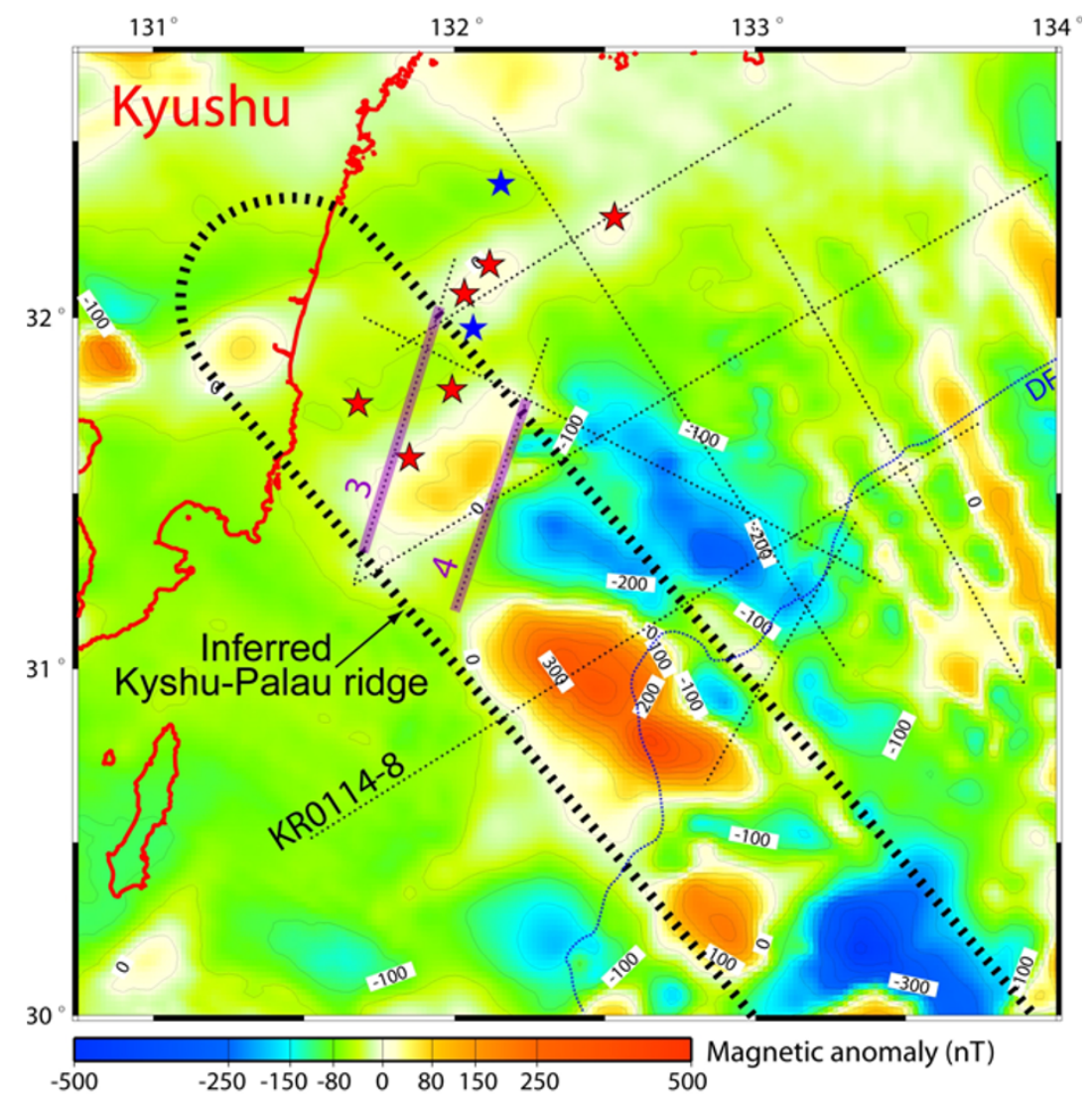

Fig. 3. Magnetic anomaly map (GSJ and CCCOGP, 1996) in the Hyuga segment (location shown as large rectangle with yellow thin line on Fig. 1). Heavy black dotted line marks the inferred Kyushu-Palau ridge. Note that the geomagnetic lineation of the Kyushu-Palau ridge identified on the MCS profile is continuously recognized from Shikoku Basin to the east Kyushu through the forearc region. The forearc magnetic lineation zone within the Kyushu-Palau ridge covers the intense crustal deformation area inferred from the OBS crustal velocity models on heavy purple parts on lines 3 and 4 (Ichikawa, 1997). 
depth around SP 2000, which is consistent with southwestward slab tilting suggested by seismicity data (Ishihara and Yoshida, 1992). A clear décollement reflection is observed between SP 2700 and 5000. The décollement reflection is identified down to $\sim 7 \mathrm{~km}$ depth, implying that the décollement may shift to the top (basal décollement) of the oceanic crust at deeper level and eventually accumulate tectonic stresses between upper and lower plates. This profile reveals an oceanic basement high on the subducting PSP beneath the accretionary wedge between SP 2400 and 3850 . The basement high with an irregular surface is characterized by three peaks around SP 2450, 3050, and 3650 , which are $\sim 0.5-1.5 \mathrm{~km}$ higher than oceanic crust in the Nanaki Trough. These basement peaks are roughly concordant with seafloor topographic highs, suggesting that the subducted basement might be responsible for the overriding plate deformation. Particularly, the seafloor topographic bulge around SP 3050 is noticeable in that the basement peak below it coincides with positive magnetic anomaly higher than $300 \mathrm{nT}$ (Fig. 3). Taking into account that the basement high exists on the forearc extension of the Kyushu-Palau ridge seen in the Shikoku Basin, we interpret it as the subducting Kyushu-Palau ridge on the descending PSP. Unfortunately, a similar basement high is not imaged on other MCS profiles on strike lines KR9810-4 and KR0114-9, probably because of poor penetration of seismic waves and/or low acoustic impedance (velocity $\times$ density) which may be attributable to the overriding plate deformation suggested by the OBS velocity structure (Ichikawa, 1997).

Geomagnetic lineations (GSJ and CCCOGP, 1996) of the Shikoku Basin are continuously identified beneath the forearc wedge toward Shikoku Island beyond the deformation front of the Nankai Trough margin (Fig. 3). Geomagnetic lineations beneath the forearc wedge have been commonly documented in various convergent plate margins, for instance, Chile Trench (Yanez et al., 2001) and Kuril Trench (Yamazaki and Okamura, 1989). Such a geomagnetic anomaly signature helps us trace the forearc extension of the Kyushu-Palau ridge identified on the MCS profile. The geomagnetic lineation of the Kyushu-Palau ridge is continuously recognized from Shikoku Basin to east Kyushu through the forearc region (Fig. 3). Interestingly, the magnetic lineation zone is roughly consistent with the forearc area of the intense crustal deformation inferred from the OBS crustal velocity models on lines 3 and 4 (Ichikawa, 1997), which suggests that the subducted Kyushu-Palau ridge preserving the magnetic anomaly signature may be responsible for the forearc wedge deformation.

The forearc area overlying the inferred subducting Kyushu-Palau ridge (Fig. 1) shows disturbed seafloor topography compared with the forearc wedge off Shikoku Island, supporting a causal relationship between the ridge subduction and the forearc deformation in the Hyuga segment. Particularly, the bathymetric data (Fig. 1) show a remarkable seafloor reentrant structure immediately south of the MCS line KR0114-8, whose feature is in good agreement with that from sandbox modeling result (Dominguez et al., 2000) of seamount or ridge subduction beneath accretionary wedge. In combination of the MCS reflection pro- file, geomagnetic signature, seafloor topographic features, wide-angle OBS refraction profiles (Ichikawa, 1997), and on-land geomorphologic evidence (Nakada et al., 2002), we infer that the $\sim 70$-km-wide subducted Kyushu-Palau ridge influences at least up to the eastern part of Kyushu arc through the forearc wedge, as seen in Figs. 1 and 3.

\section{Discussion: Implications for the Hyuga Megathrust Earthquake Rupture}

In addition to its importance to forearc deformation, the subducted Kyushu-Palau ridge seems to be related to seismotectonics in the Hyuga segment. There are many arguments on the possible effect (i.e., either seismic asperity or barrier) of subducting bathymetric features such as seamounts or ridges. While some regard those as seismic asperities in various convergent plate margins, for example, Costa Rica margin (von Huene et al., 2000; Bilek et al., 2003), Java Trench (Abercrombie et al., 2001), Tonga Trench (Christensen and Lay, 1988), and Peru-Chile Trench (Spence et al., 1999), others discuss their roles as seismic barriers in the Nankai Trough (Kodaira et al., 2000; Park et al., 2003). The Kyushu-Palau ridge in the Hyuga segment provides a unique opportunity to discuss these effects from both viewpoints.

\subsection{Seismic asperity}

Megathrust earthquake rupture in subduction zones is highly influenced by seafloor bathymetric features such as oceanic fracture zones, seamounts, and ridges, which are more likely to increase local coupling where these features subduct. Scholz and Small (1997) considered that the subduction of a large seamount will increase the normal stress across the subduction interface and hence will enhance seismic coupling. Cloos (1992) viewed that subducting basaltic seamounts may act as the kind of seismic asperity (region of high moment release) whose rupture commonly causes thrust-type earthquakes at convergent plate margins. He speculated that the earthquakes might be nucleated where basaltic seamounts are jammed against the top of the shear zone at the base of the overriding plate. In contrast, recent seismic surveys in the Japan Trench suggests that interplate coupling is weak over a large seamount which is being subducted near a region of repeating earthquakes of magnitude $\sim 7$ (Mochizuki et al., 2008). A large rupture area occurred in front of the seamount subducted beneath the Japan Trench margin.

In the Hyuga segment, the Kyushu-Palau ridge may be a complex of closely spaced isolated seamounts, rather than a uniformly elongate body with the same height, as seen in the bathymetry (Fig. 1). The subducted Kyushu-Palau ridge with excess mass may be relatively buoyant (e.g., Kelleher and McCann, 1976), and thus is more likely to resist subduction upon collision with the overriding plate at depth, inducing tectonic stresses. Most of the thrust-type intermediate-class (magnitude 6 or 7) earthquakes that occurred in the Hyuga segment since 1960's appear to have been concentrated in and around the forearc area overlying the inferred subducting Kyushu-Palau ridge, as seen in Figs. 1 and 4. For example, a precise source process study (Yagi et al., 1999) on recent two 1996 thrust-type earthquakes $\left(M_{\mathrm{s}}=6.7\right)$ whose epicenters are definitely located 


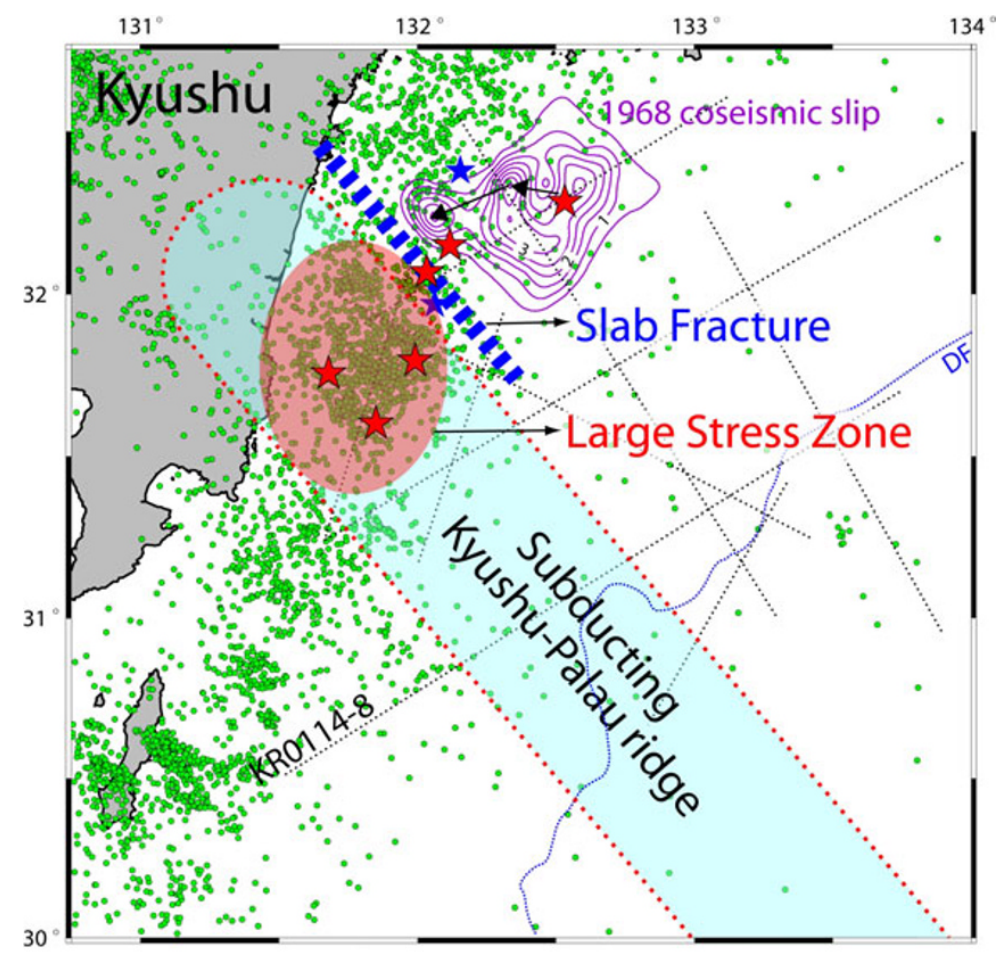

Fig. 4. Schematic diagram illustrating the proposed locally large stress zone (light pink ellipse) and slab fracture (heavy blue dotted line) caused by the Kyushu-Palau ridge subduction (thin red dotted line). Small green circles mark seismicity $(M \geq 2$, focal depth $\leq 60 \mathrm{~km})$ during the period of 1985 to 1998 (Japan University Network Earthquake Catalog). The northwest Kyushu-Palau ridge (light pink ellipse) off east Kyushu is marked by a seismicity cluster. The 1968 Hyuga $(M=7.5)$ coseismic slip contours with thin purple lines is given by Yagi et al. (1998). The arrows within the contour map indicate the rupture propagation toward the next subevents. Note that the 1968 Hyuga event stopped at the northeast flank region of the Kyushu-Palau ridge.

in the inferred Kyushu-Palau ridge zone, indicates that they have apparently occurred along the plate boundary at $\sim 10$ $20 \mathrm{~km}$ depth. We speculate that there is locally "large tectonic stress" (Fig. 4) at the contact zone between the subducted Kyushu-Palau ridge and base of the overriding plate at depth, in which the historic thrust-type earthquakes occur to relax the accumulated stresses. The large stress zone could be in front of a possible, isolated seamount belonging to the Kyushu-Palau ridge. Assuming that a zone of positive magnetic anomaly between OBS lines 3 and 4 corresponds to the isolated seamount (Fig. 3), as in case of the MCS profile KR0114-8 or along the Zenisu ridge (Le Pichon et al., 1996), three thrust-type earthquakes of magnitude 6 to 7 might occur in front of the seamount. Moreover, background seismicity concentrates in front of the seamount, rather than over it. A study on shear stress field in the Hyuga segment suggested from OBS observations that south region including the Kyushu-Palau ridge has higher shear stress than north region (Uehira, 2007). We propose that the subducted Kyushu-Palau ridge might serve as seismic asperity in the Hyuga segment.

\subsection{Seismic barrier}

It is noticeable that coseismic rupture (Yagi et al., 1998) of the 1968 Hyuga earthquake $(M=7.5)$, which is recorded as the largest thrust-type earthquake that has ever occurred in the Hyuga segment, has failed to propagate over the northeast flank of the subducted Kyushu-Palau ridge (Fig. 4). Yagi et al. (1998) suggested that a slab fracture might inhibit the 1968 Hyuga earthquake rupture propa- gation. Background seismicity observations (e.g., Nagamune and Tashiro, 1989; Kakuta et al., 1991; Ishihara and Yoshida, 1992) support the presence of a similar fracture in the Hyuga segment, which is characterized by low intraslab seismicity. However, the slab fracturing mechanism has been poorly understood.

We note from the MCS profile (Fig. 2) that the elevation of the ridge is higher than that of the Nankai Trough oceanic crust. The subducted Kyushu-Palau ridge with excess mass may be relatively buoyant, and thus its adjacent slab is more likely to tear and result in such a slab fracture when it subducts deeper, as in the case of the Carnegie ridge subduction in the North Andean margin (Gutscher et al., 1999). The inferred northwest Kyushu-Palau ridge off east Kyushu (Fig. 4), which is characterized by a background seismicity cluster, is located immediately west of the 1968 Hyuga coseismic slip. The seismicity cluster enables us to separate the Kyushu-Palau ridge region from the 1968 coseismic rupture region. We propose that a northeast flank region of the subducted Kyushu-Palau ridge is eligible for the slab fracture. The slab fracture owing to the buoyant Kyushu-Palau ridge subduction might play a role as a seismic barrier interfering with coseismic rupture propagation of the megathrust earthquakes in the Hyuga segment.

\section{Conclusions}

A seismic reflection profile on strike line reveals the $\sim 70$ $\mathrm{km}$-wide Kyushu-Palau ridge that subducts immediately beneath the forearc accretionary wedge in the Hyuga segment, 
the westernmost Nankai subduction zone. Geomagnetic anomaly signature, seafloor topographic features, and previous wide-angle refraction data and on-land geomorphologic evidence enable us to trace the forearc extension of the subducted ridge up to east Kyushu. The subducted KyushuPalau ridge with excess mass may be relatively buoyant, and thus is more likely to resist subduction upon collision with the overriding plate at depth in the Hyuga segment. The historic thrust-type intermediate-class earthquakes at the forearc area overlying the inferred subducting KyushuPalau ridge suggest that there may be locally large tectonic stress at the contact zone between the subducted ridge and base of the overriding plate, which often allows a high moment release. The flank regions of the subducted buoyant Kyushu-Palau ridge are more likely to tear and result in the slab fracturing when the ridge subducts deeper. The subducted Kyushu-Palau ridge may serve not only as a seismic asperity at depth, but also produce the slab fracture as a seismic barrier inhibiting coseismic rupture propagation of adjacent megathrust earthquakes, for instance, as in case of the 1968 Hyuga earthquake $(M=7.5)$.

Acknowledgments. The bathymetric data (Fig. 1) compiled by the Hydrographic and Oceanographic Department, Japan Coast Guard. We thank the captain, crew, and technical staff of the R/V Kairei of JAMSTEC for their support in acquiring the MCS data. We also acknowledge Yuji Yagi for the coseismic slip data of the 1968 Hyuga earthquake. We are deeply indebted to Kelin Wang and an anonymous reviewer for their constructive comments and suggestions to improve the manuscript.

\section{References}

Abercrombie, R. E., M. Antolik, K. Felzer, and G. Ekstrom, The 1994 Java tsunami earthquake: Slip over a subducting seamount, J. Geophys. Res., 106, 6595-6607, 2001

Ando, M., Source mechanisms and tectonic significance of historical earthquakes along the Nankaki trough, Tectonophysics, 27, 119-140, 1975.

Bilek, S. L., S. Y. Schwartz, and H. R. DeShon, Control of seafloor roughness on earthquake rupture behavior, Geology, 31, 455-458, 2003.

Christensen, D. H. and T. Lay, Large earthquakes in the Tonga region associated with subduction of the Louisville Ridge, J. Geophys. Res., 93, 13367-13389, 1988

Cloos, M., Thrust-type subduction zone earthquakes and seamount asperities: A physical model for seismic rupture, Geology, 20, 601-604, 1992.

Dominguez, S., J. Malavieille, and S. E. Lallemand, Deformation of accretionary wedge in response to seamount subduction: Insights from sandbox experiments, Tectonics, 19, 182-196, 2000.

Geological Survey of Japan (GSJ) and Coordinating Committee for Coastal and Offshore Geoscience Programs (CCCOGP) in East and Southeast Asia, Magnetic anomaly map of east Asia 1:4,000,000 CDROM version. 1996.

Gutscher, M.-A., J. Malavieille, S. Lallemand, and J.-Y. Collot, Tectonic segmentation of the North Andean margin: impact of the Carnegie Ridge collision, Earth Planet. Sci. Lett., 168, 255-270, 1999.

Ichikawa, G., Ocean bottom seismographic experiment to study crustal structure in Hyuga-nada, M.Sc. Thesis, University of Hokkaido, 1997 (in Japanese with English abstract).

Ishihara, K. and A. Yoshida, Configuration of the Philippine sea slab and seismic activity in and around Kyushu, Zisin, 45, 45-51, 1992 (in Japanese with English abstract).

Kakuta, T., H. Miyamachi, and A. Takagi, Intermediate earthquakes in a northern part of the Kyushu-Ryukyu arc, Zisin, 44, 63-74, 1991 (in Japanese with English abstract).

Kelleher, J. and W. McCann, Buoyant zones, great earthquakes, and unstable boundaries of subduction, J. Geophys. Res., 81, 4885-4896, 1976.

Kobayashi, K. and M. Nakada, Magnetic anomalies and tectonic evolution of the Shikoku inter-arc basin, J. Phys. Earth, 26, S391-S402, 1978.

Kodaira, S., N. Takahashi, A. Nakanishi, S. Miura, and Y. Kaneda, Subducted seamount imaged in the rupture zone of the 1946 Nankaido earthquake, Science, 289, 104-106, 2000.

Le Pichon, X., T. Iiyama, H. Chamley, J. Charvet, M. Faure, H. Fujimoto, T. Furuta, Y. Ida, H. Kagami, S. Lallemant, J. Leggett, A. Murata, H. Okada, C. Rangin, V. Renard, A. Taira, and H. Tokuyama, The eastern and western ends of Nankai Trough: results of Box 5 and Box 7 Kaiko survey, Earth Planet. Sci. Lett., 83, 199-213, 1987.

Le Pichon, X., S. Lallemant, H. Tokuyama, E. Thoue, P. Huchon, and P. Henry, Structure and evolution of the backstop in the eastern Nankai trough area (Japan): Implications for the soon-to-come Tokai earthquake, Island Arc, 5, 440-454, 1996.

Liu, Z. and N. Bleistein, Migration velocity analysis: Theory and an iterative algorithm, Geophysics, 60, 142-153, 1995.

Mochizuki, K., T. Yamada, M. Shinohara, Y. Yamanaka, and T. Kanazawa, Weak interplate coupling by seamounts and repeating M 7 earthquakes, Science, 321, 1194-1197, 2008.

Nagamune, T. and H. Tashiro, Shape of the Wadati-Benioff zone beneath Kyushu, Japan, Zisin, 42, 13-19, 1989 (in Japanese with English abstract).

Nakada, M., M. Tahara, H. Shimizu, S. Nagaoka, K. Uehira, and S. Suzuki, Late Pleistocene crustal uplift and gravity anomaly in the eastern part of Kyushu, Japan, and its geophysical implications, Tectonophysics, 351, 263-283, 2002.

Nishimura, S., M. Ando, and S. Miyazaki, Inter-plate coupling along the Nankai Trough and southeastward motion along southern part of Kyushu, Zisin, 51, 443-456, 1999 (in Japanese with English abstract).

Okino, K., Y. Shimakawa, and S. Nagaoka, Evolution of the Shikoku Basin, J. Geomag. Geoelectr., 46, 463-479, 1994.

Park, J.-O., G. F. Moore, T. Tsuru, S. Kodaira, and Y. Kaneda, A subducted oceanic ridge influencing the Nankai megathrust earthquake rupture, Earth Planet. Sci. Lett., 217, 77-84, 2003.

Scholz, C. H. and C. Small, The effect of seamount subduction on seismic coupling, Geology, 25, 487-490, 1997.

Seno, T., S. Stein, and A. E. Gripp, A model for the motion of the Philippine Sea plate consistent with NUVEL-1 and geological data, J. Geophys. Res., 98, 17941-17948, 1993.

Shiono, K., T. Mikumo, and Y. Ishikawa, Tectonics of the Kyushu-Ryukyu arc as evidenced from seismicity and focal mechanisms of shallow to intermediate depth earthquakes, J. Phys. Earth, 28, 17-43, 1980.

Spence, W., C. Mendoza, E. R. Engdahl, G. L. Choy, and E. Norabuena, Seismic subduction of the Nazca Ridge as shown by the 1996-97 Peru earthquakes, Pure Appl. Geophys., 154, 753-776, 1999.

Sugiyama, Y., Neotectonics of Southwest Japan due to the right-oblique subduction of the Philippine Sea Plate, Geofis. Int., 33, 53-76, 1994.

Tahara, M., K. Uehira, H. Shimizu, M. Nakada, T. Yamada, K. Mochizuki, M. Shinohara, M. Nishino, R. Hino, H. Yakiwara, H. Miyamachi, K. Umakoshi, M. Goda, N. Matsuwo, and T. Kanazawa, Seismic velocity structure around the Hyuganada region, Southwest Japan, derived from seismic tomography using land and OBS data and its implications for interplate coupling and vertical crustal uplift, Phys. Earth Planet. Inter., 167, 19-33, 2008.

Uehira, K., The stress field of the Hyuga-nada region, southwest Japan, deduced from ocean-bottom seismic observations, D.Sc. Thesis, University of Tokyo, 2007 (in Japanese with English abstract).

von Huene, R., C. R. Ranero, W. Weinrebe, and K. Hinz, Quaternary convergent margin tectonics of Costa Rica, segmentation of the Cocos plate, and Central American volcanism, Tectonics, 19, 314-334, 2000.

Yagi, Y., M. Kikuchi, S. Yoshida, and Y. Yamanaka, Source process of the

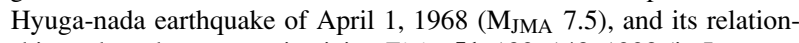
ship to the subsequent seismicity, Zisin, 51, 139-148, 1998 (in Japanese with English abstract).

Yagi, Y., M. Kikuchi, S. Yoshida, and T. Sagiya, Comparison of the coseismic rupture with the aftershock distribution in the Hyuga-nada earthquakes of 1996, Geophys. Res. Lett., 26, 3161-3164, 1999.

Yamazaki, T. and Y. Okamura, Subducting seamounts and deformation of overriding forearc wedges around Japan, Tectonophysics, 160, 207-229, 1989.

Yanez, G. A., C. R. Ranero, R. von Huene, and J. Diaz, Magnetic anomaly interpretation across the southern central Andes $\left(32^{\circ}-34^{\circ}\right)$ : The role of the Juan Fernandez Ridge in the late Tertiary evolution of the margin, $J$. Geophys. Res., 106, 6325-6345, 2001.

J.-O. Park (e-mail: jopark@ori.u-tokyo.ac.jp), T. Hori, and Y. Kaneda 